\author{
Arnold Karateev, Denis Litvinov \\ and Olesya Kalkamanova
}

\title{
"N ON ISOCYAN ATE" POLYHYDROXY URETHANES BASED ON THE RAW MATERIAL OF A PLANT ORIGIN
}

\author{
National Technical University "Kharkiv Polytechnic Institute" \\ 21, Frunze str., 61002 Kharkiv, Ukraine; \\ arnoldkarat@ukr.net
}

Received: February 10, 2014 / Revised: February 12, 2014 / Accepted: J une 02, 2014

(C) Karateev A., Litvinov D., Kalkamanova O., 2014

\begin{abstract}
New furfuryl oxypropyl cyclocarbonate (FOPCC)-based "nonisocyanate" polyhydroxy urethanes (PHU) (FOPCC being a product of recycled renewable raw materials) have been synthesized. The urethane formation reaction was investigated using infrared spectroscopy. The method of differential scanning calorimetry was used for the studies of the kinetics of reactions that form PHU, in particular the urethane-formation reaction and Diels-Alder reaction. It has been shown that FOPCC derivatives can be polymerized in the presence of a complex onium catalyst. Thermally reversible and thermally irreversible cross-linked PHUs have been produced.
\end{abstract}

Keywords: nonisocyanate polyhydroxy urethanes, renewable raw material, furfuryloxypropyl cyclocarbonates, Diels-Alder reaction.

\section{Introduction}

Starting from the 90's of the XX century much attention has been paid to a new scientific trend observed in the development of the contemporary chemistry, in particular the so-called "green chemistry", which provides for the development of chemical products and processes using no harmful substances. One of the key trends in the development of "the green chemistry" is the use of renewable raw material as a carbon source for chemical industry [1-5].

At the present time the primary carbon source for chemical industry is presented by natural resources (oil, gas, and coal), however these Earth resources are exhaustible. Their production is relocated to hard-to-reach areas (the North, Arctic shelf, and the sea bottom). As a result the cost of hydrocarbon raw material is continuously growing.
The search for alternative energy sources and the development of systems designed for the capture of industrial $\mathrm{CO}_{2}$ emissions is a topical trend in contemporary science and the use of $\mathrm{CO}_{2}$ as a raw material for chemical industry (at relatively mild reaction conditions) will allow us to reduce $\mathrm{CO}_{2}$ emissions into atmosphere and simultaneously provide alternative, renewable, nontoxic, and efficient raw material source for chemical industry. An example of the chemical disposal of $\mathrm{CO}_{2}$ on industrial scale is the synthesis of cyclocarbonates (CC), to which special attention has been paid for the last twenty years, because it is a new class of compounds used for the production of ecologically friendly "nonisocyanate" polyhydroxy urethanes (PHU) of linear and cross-linked structures [6-9].

This scientific paper delves into the creation of new "nonisocyanate" PHU using available renewable raw materials. A major monomer used for the synthesis of nonisocyanate PHU is 4-(furfuryloxymethyl-1,3dioxylane-2-one or furfuryloxypropyl cyclocarbonate (FOPCC), which is synthesized from carbon dioxide and furfuryl glycidyl ether (FGE), the latter being the product of biomass recycling. The synthesis of the FOPCC-based PHU presupposes the use of two reactions, in particular the urethane formation reaction between the FOPCC and the diamines of a different structure:

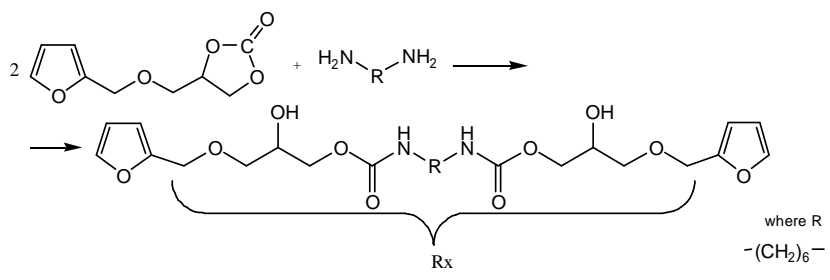


and Diels-Alder (D-A) reaction between the furan-bearing glycol urethanes and the bismaleimides, that results in the formation of a linear PHU:

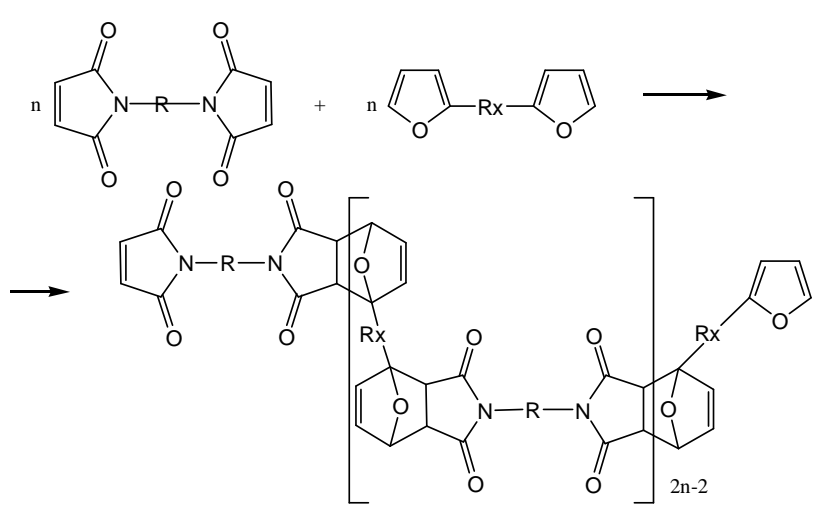

The use of three functional monomers allows for the formation of PHU of a cross-linked structure.

\section{Experimental}

\subsection{M aterials}

Furfuryl alcohol (FA), epichlorohydrine (ECH), hexamethylenediamine (HMDA), diethylenetriamine (DETA), and maleic anhydride (MA) are commercial reagents that were bought from the "Laboratory Mir Ltd." Company. The ground substance content (GSC) for all reagents is $99 \%$. Prior to the use FA and $\mathrm{ECH}$ were subjected to distillation and drying over the calcium chloride.

\subsection{Synthesis}

Furfuryl glycidyl ether (FGE) was synthesized by condensation reaction of FA with ECH using the methods described in [10]. The obtained $\mathrm{ECH}$ has $T_{\text {boil. }}=373$ $377 \mathrm{~K}$ at $11 \mathrm{~mm}$ mercury column; $n_{\mathrm{d}}{ }^{20}=1.4810$ (it agrees with literature data), epoxy number is $27.3 \%$. The ground substance content is $98 \%$. The data of nuclear paramagnetic resonance ${ }^{1} \mathrm{H}$ NMR are given in Table 1.

Hexamethylene bis-maleimide (HMBM) was synthesized using the methods given in [11]. The obtained HMBM is a crystalline substance of white color with $T_{m}=383 \mathrm{~K}$. The ${ }^{1} \mathrm{H}$ NMR data are given in Table 1.

FOPCC was synthesized by the FGE and $\mathrm{CO}_{2}$ interaction reaction in supercritical state (Scheme 1). FGE was loaded to fill $1 / 10$ of the reactor volume, and the initial pressure of $\mathrm{CO}_{2}$ was 3.2 $\mathrm{MPa}$. We used tetraphenyl phosphonium bromide ( 2 mas \%) as a catalysts, and the reaction temperature was $363 \mathrm{~K}$. The synthesis lasted for $9 \mathrm{~h}$. The product output in terms of the conversion of epoxy groups was $99.3 \%$. The synthesized FOPCC is an agile liquid of a hazel color. After vacuum distillation
FOPCC acquires hardly noticeable pale yellow color; $T_{\text {boil. }}=$ $=465-467 \mathrm{~K}$ at $11 \mathrm{~mm} ; n_{\mathrm{d}}{ }^{20}=1.4920$; density is $1.45 \mathrm{~g} / \mathrm{cm}^{3}$. ${ }^{1} \mathrm{H}$ NMR data are given in Table 1 . The IR spectrum shows the appearance of a peculiar absorption band of a carbonyl group in the cyclocarbonate ring at $1796 \mathrm{~cm}^{-1}$.

Chlorine methylene cyclocarbonate (CMCC) was synthesized by the $\mathrm{ECH}$ and $\mathrm{CO}_{2}$ interaction reaction in the supercritical state by analogy with the FOPCC synthesis. The product yield was $99 \%$. The synthesized CMCC was an agile liquid of a pale yellow color; $T_{\text {boil. }}=419-421 \mathrm{~K}$ at $11 \mathrm{~mm}$ mercury column; $n_{\mathrm{d}}{ }^{20}=1.4695$; density is $1.22 \mathrm{~g} / \mathrm{cm}^{3}$. ${ }^{1} \mathrm{H}$ NMR data are given in Table 1. The IR spectrum shows the appearance of a peculiar absorption band of the carbonyl group in the cyclocarbonate ring at $1796 \mathrm{~cm}^{-1}$.

Ethane bicyclocarbonate (EBCC) was synthesized using the Wurtz reaction through the interaction of CMCC with metallic sodium in the environment of absolutely dry toluene at 303-313 K during $6 \mathrm{~h}$. EBCC synthesized on the basis of CMCC is a viscous liquid of a hazel color; $n_{\mathrm{d}}{ }^{20}=1.4705$; density is $1.27 \mathrm{~g} / \mathrm{cm}^{3}$. The product yield in terms of the reaction salt is $90 \%$. The IR spectrum still shows a peculiar absorption band of the carbonyl group in the cyclocarbonate ring at $1796 \mathrm{~cm}^{-1}$.

Bis-(furfurylpropoxy) diglycol urethane (BFPU) (monomer I) was synthesized through the interaction of HMDA with FOPCC with the mole ratio of 1:2 (Scheme 1). The reaction was carried out at $373 \mathrm{~K}$, and it was controlled using the method of IR spectroscopy. The synthesized monomer I is a viscous liquid of a deep-brown color.

Bis-(furfurylpropoxy) oligoglycol urethane (monomer II) was synthesized through the interaction of HMDA with EBCC and FOPCC with the mole ratio of 6:5:2, respectively (Scheme 2). The synthesis was conducted in two stages. During the first stage we obtained oligoglycol urethane with end aminogroups and during the second stage the reaction of the end aminogroups of oligoglycol urethane with FOPCC results in the formation of the monomer II. The reaction conditions are analogous to those used for the synthesis of the monomer I. The reaction was controlled using the method of IR spectroscopy. The synthesized monomer II is a very viscous liquid of a deep-brown color.

Tris-(furfurylpropoxy) hydroxydiglycol urethane (TFPHFGU) (monomer III) was synthesized through the interaction of DETA with FOPCC and FGE with the mole ratio of 1:2:1, respectively (Scheme 2). The synthesis was conducted in two stages. During the first stage the DETA and FOPCC-based diglycol urethane were obtained. The reaction was controlled using the IR spectroscopy method, during the second stage the monomer III was obtained through the interaction of FGE with the secondary amine group (the reaction was controlled by a change in the epoxy number). The reaction conditions are analogous to those used for the synthesis of the monomers I and II. 
Characteristics of ${ }^{1} \mathrm{H}-\mathrm{NMR}$ spectra of the synthesized monomers $\left(200 \mathrm{MHz} ;\left(\mathrm{CD}_{3}\right)_{2} \mathrm{SO} ; \delta(\mathrm{ppm})\right)$

\begin{tabular}{|c|c|c|}
\hline 1 & $\underbrace{2}_{0} \underbrace{3}_{4}$ & $\underbrace{\mathrm{Cl}}_{1} \overbrace{0^{\prime}}^{3}$ \\
\hline $\begin{array}{c}7 \mathrm{H}(2.47-2.72) \mathrm{mt} ; 6 \mathrm{H}(3.0-3.1) \mathrm{m} ; \\
5 \mathrm{H}(3.2-3.28 ; 3.65-3.7) \mathrm{dd} ; 4 \mathrm{H}(4.43) \mathrm{s} ; \\
2.3 \mathrm{H}(6.42) \mathrm{s} ; 1 \mathrm{H}(7.63) \mathrm{s}\end{array}$ & $\begin{array}{c}5 \mathrm{H}(3.52-3.6 ; 3.64-3.72) \mathrm{dd} ; 7 \mathrm{H}(4.16- \\
4.54) \mathrm{mt} ; 4 \mathrm{H}(4.48) \mathrm{s} ; 6 \mathrm{H}(4.85-4.95) \mathrm{m} ; \\
2.3 \mathrm{H}(6.42) \mathrm{s} ; 1 \mathrm{H}(7.63) \mathrm{s}\end{array}$ & $\begin{array}{l}3 \mathrm{H}(4.2-4.64) \mathrm{qt} ; 2 \mathrm{H}(5.02-5.16) \mathrm{m} ; \\
\quad 1 \mathrm{H}(3.84-3.92 ; 3.94-4.04) \mathrm{dd}\end{array}$ \\
\hline$\prod_{0}^{11}$ & O & 1 \\
\hline $4 \mathrm{H}(1.17) \mathrm{s} ; 3 \mathrm{H}(1.4-1.4$ & $\mathrm{H}(3.32-3.37) \mathrm{t} ; 1 \mathrm{H}(6.97) \mathrm{s}$ & $\begin{array}{c}3 \mathrm{H}(2.64-2.86) \mathrm{qt} ; 2 \mathrm{H}(3.16-3.26) \mathrm{m} ; \\
1 \mathrm{H}(3.46-3.58 ; 3.82-3.92) \mathrm{dd}\end{array}$ \\
\hline
\end{tabular}

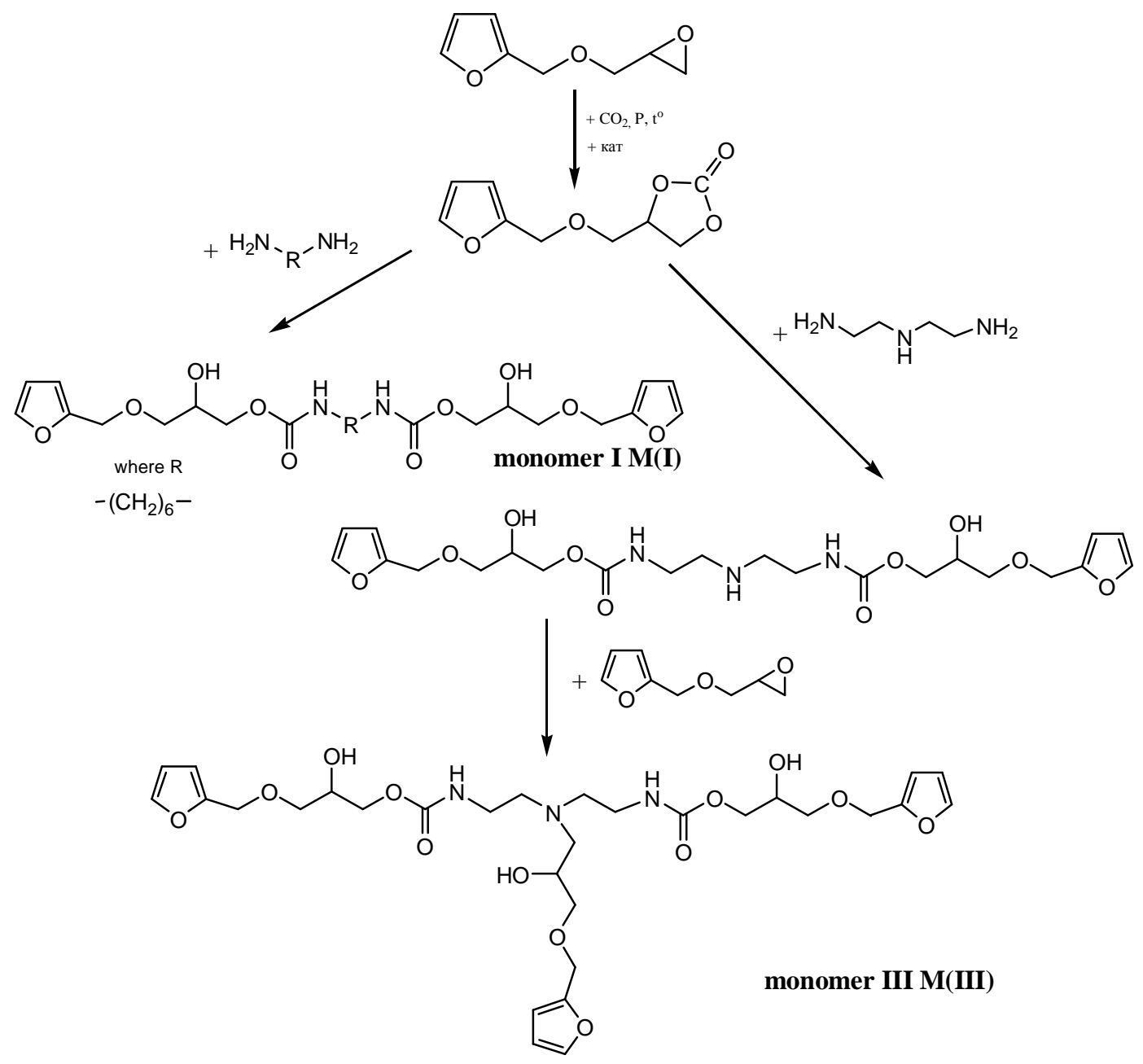

Scheme 1. Synthesis of FOPCC and its derivatives 

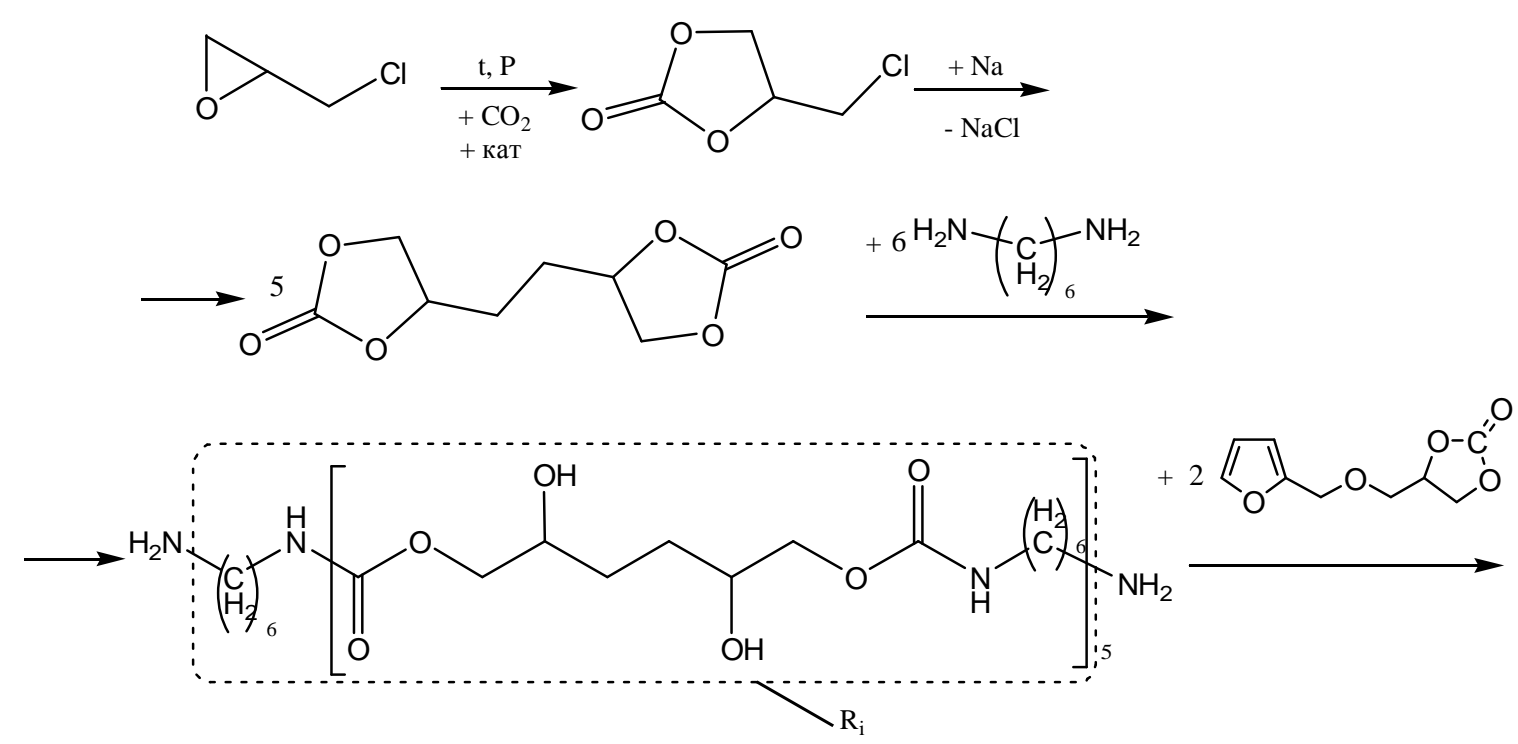<smiles>C[As]CCCCCCCOC(=O)NNNC(=O)OCC(O)COCc1ccco1</smiles>

Scheme 2. Synthesis of linear FOPCC derivative - based PHUs

PHU synthesis. HMBM was dissolved in the acetone / butyl acetate mixture (50:50); it was added in appropriate mole ratio to the furan-bearing hydroxyurethane and applied onto the metal substrate. The addition compound formation reaction was carried out at $323 \mathrm{~K}$. All the coatings were dried to the degree of 3 during 50-55 min. A total hardening time at which the hardness stops to change varies in the range of $2.5-3 \mathrm{~h}$.

The complex onium catalyst (COC) $\mathrm{Et}_{3} \mathrm{PhCH}_{2} \mathrm{~N} \cdot \mathrm{FeCl}_{4}$ was obtained using the methods given in $[12,13]$.

\subsection{Experimental Procedure}

To determine the kinetic parameters of urethane formation reactions between FOPCC and HMDA and also the addition compound formation reaction D-A between the FOPCC and the HMDA we used the method of differential scanning calorimetry (DSC). The experiment was carried out in nonisothermal conditions. Mathematical calculations were done using the basic differential equation for isothermal conditions:

$$
d \alpha / d \tau=k(T) \cdot f\left(\alpha_{i}\right)
$$

where $d \alpha / d \tau$ is the reaction rate; $k(T)$ is the rate constant corresponding to the Arrhenius equation; $f\left(\alpha_{i}\right)$ is the kinetic equation; $\alpha_{i}$ is the degree of the reaction completion by the time $\tau_{i}$.

The following kinetic equation was used for computations:

$$
f\left(\alpha_{i}\right)=\left(1-\alpha_{i}\right)^{n}
$$

where $n$ is the reaction order.

For the nonisothermal experiment, which is carried out at a constant heating rate $\beta=d T / d \tau=$ const the Eq. (1), using the Eq. (2), can be expressed as:

$$
d \alpha / d T=\frac{A}{\beta} \exp (-E / R T) \cdot f\left(1-\alpha_{i}\right)^{n}
$$

where $\beta$ is the heating rate; $E$ is the activation energy; $R$ is the gas constant; $T$-is the temperature in Kelvin degrees.

After the logarithm has been found and the regrouping has been done the Eq. (3) takes the appropriate form required for the computation of kinetic parameters of the reaction [14]:

$$
\ln \alpha_{i}^{\prime}-n \ln \left(1-\alpha_{i}\right)=\ln \frac{A}{\beta}-\frac{E}{R T}=\ln k(T)
$$

The kinetic analysis is reduced to the derivation of the linear relationship of logarithmic function for the left side of the Eq. (3) as a function of the reverse temperature, through the selection of the order of the reaction. 
Calculated kinetic parameters were checked using the main analytic equation that was derived through the integration of the Eq. (1) with its further transformation to the type used for the nonisothermal experiment [15]:

$$
g\left(\alpha_{i}\right)=\frac{A R T_{i}^{2}}{\beta E} \exp \left(-E / R T_{i}\right)
$$

where $g\left(\alpha_{i}\right)$ is the integral form of the kinetic equation;

$$
\begin{array}{ll}
g\left(\alpha_{i}\right)=-\ln \left(1-\alpha_{i}\right) \quad \text { for } & n=1 ; \\
g\left(\alpha_{i}\right)=(1-n)^{-1}\left(1-\left(1-\alpha_{i}\right)^{1-n}\right) \text { for } n \neq 1 . &
\end{array}
$$

The kinetic parameters of reactions were also estimated using the Kissinger method. The advantage of this method is that it is necessary to know just the maximum temperature of thermal effect $\left(T_{\max }\right)$, the computations are done by the graphic processing of the equation [15];

$$
\ln \left(\frac{\beta_{j}}{T_{i}^{2}}\right)=\ln \left(\frac{A_{i} R}{E_{i}} \cdot \frac{1}{g\left(\alpha_{i}\right)}\right)-\frac{E_{i}}{R} \cdot \frac{1}{T_{i}}
$$

where index $i$ corresponds to the fixed values of the conversion $\alpha_{i}$ for each heating rate $\beta_{j}$; the value $E_{i}$ is calculated using the graphic processing of the Eq. (6) in the coordinates $\ln \left(\frac{\beta_{j}}{T_{i}^{2}}\right)=f\left(1 / T_{i}\right)$.

All the reactions that were investigated using the DSC method were carried out in the DMSO solution. For this purpose HMDA and HMBM were dissolved in dimethyl sulphoxyde with the mass share of $50 \%$.

The PMR spectroscopy was carried out using spectrophotometer Varion Mercury VX-200, and solvent $\left(\mathrm{CD}_{3}\right)_{2} \mathrm{SO}$.

The IR spectroscopy was carried out using spectrophotometer Specord IR 75 with $\mathrm{NaCl}$ and $\mathrm{KBr}$ prisms.

The gel-fraction was analyzed using the device of "Sokslet" type, the DMAA solvent, and acetone.

Physical and mechanical properties of polymer coatings are measured as follows: the hardness is measured according to ISO 1522 (method A); the impact resistance is measured according to ISO 6272, and the bend elasticity is determined in compliance with ISO 1519.

\section{Results and Discussion}

The synthesis of new polymer materials always presupposes the studies of the kinetic parameters of key reactions and the choice of the optimal way of the polymer formation. Theoretically, kinetic parameters can be calculated using the Eq. (4) and one DSC thermogram. If the reaction order (it is prescribed on one's own) is known it is possible to compute two kinetic parameters $\left(E_{a}\right.$ and $A$ ) right away using the method of least squares. The compensation effect of this method always allows for the selection of a couple of values of kinetic parameters $\left(E_{a}\right.$ and $A$ ) that will describe well the given reaction; however these may not correspond to the true values. For the reliability of the obtained results it is reasonable to investigate the same reaction at different heating rates, which will allow for the accurate determination of kinetic parameters that are independent of the heating rate.

Fig. 1 gives experimental DSC thermograms of the reactions of urethane formation at different heating rates.

The value of thermal effects is $\Delta Q=79.5 \pm 1.8 \mathrm{~J} / \mathrm{g}$ whatever the heating rate is. It is indicative of the fact that the reaction progresses in the same way and this allows us to switch over to the temperature relationship of the degree of the reaction completion (Fig. 2), which is calculated using the formula:

$$
\alpha_{i}=\frac{\partial q_{i}}{\partial T_{i}} \cdot \frac{1}{\Delta Q}
$$

where $\partial q_{i}$ is the heat, which was released at $T_{i}$.

Table 2 gives some characteristics of the thermal effects of the FOPCC and HMDA interaction, in particular $T_{\max }$, and $\alpha_{\text {max }}$, the latter is the value of the degree of the reaction completion at $T_{\max }$.

Fig. 3 gives the linear relationship of the FOPCC and HMDA reaction of urethane formation within the bounds of the Eq. (4). The experimental data are the most optimally rectified to the linear relationship for all heating rates at $n=1.5$. The calculated values $E_{a}$ and $A$ are given in Table 3. Theoretical curves of the degree of the reaction completion for these kinetic parameters are shown by solid lines in Fig. 2, and were calculated using the Eq. (5).

The calculated data (Table 3 ) show that $E_{a}$ for three heating rates is $136.7 \pm 8.2 \mathrm{~kJ} / \mathrm{mol}$, and $A=$ $=(3.65 \pm 3.59) \cdot 10^{15} \mathrm{~s}^{-1}$. In contrast to $A$ the spread in parameters for $E_{a}$ is not large. Theoretical curves that are constructed using integrated kinetic parameters (Table 3) for different heating rates and most optimally match experimental data are given in Fig. 4.

The origination of the thermal effect of the urethane formation reaction is observed at about $373 \mathrm{~K}$. Proceeding from this we decided to conduct the urethane formation reaction (the synthesis of monomer I) at $373 \mathrm{~K}$. The reaction was controlled by IR-spectroscopy (Fig. 5). IR spectra were taken in the DMSO solution to reduce the intensity of the adsorption band of carbonyl group in cyclocarbonate. 


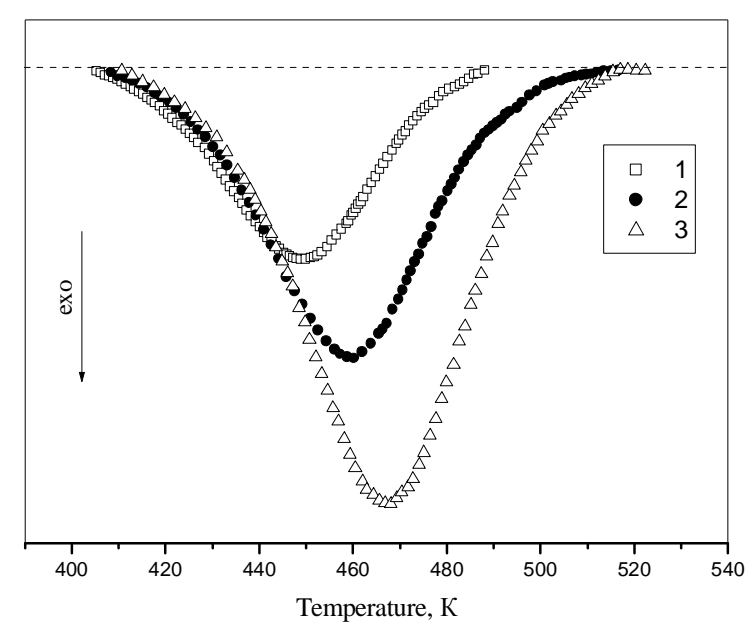

Fig. 1. Thermal effects of the urethane formation reaction between the FOPCC and the HMDA for different heating rates (K/min): $1.2(1) ; 2.0(2)$ and 2.9 (3)

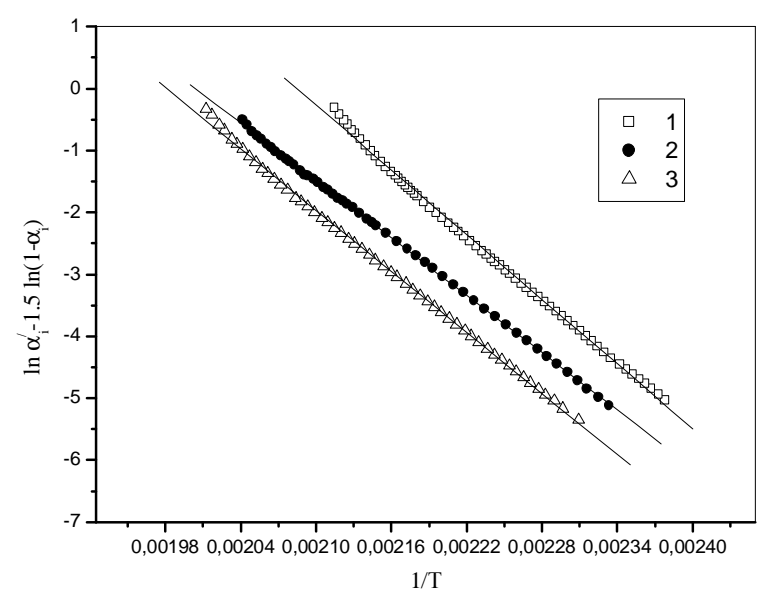

Fig. 3. The relationship $\ln \alpha_{i}^{\prime}-n \cdot \ln \left(1-\alpha_{i}\right)$ as a function of $1 /$ for the urethane formation reaction between the FOPCC and the HMDA for different heating rates (K/min): $1.2(1) ; 2.0(2)$ and $2.9(3)$

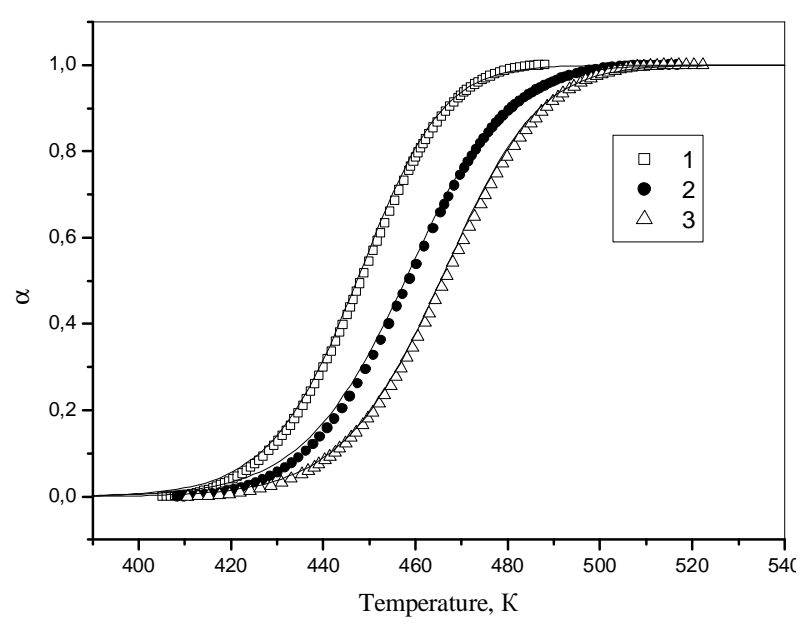

Fig. 2. The relationship of the degree of completion of the urethane formation reaction between the FOPCC and the HMDA for different heating rates (K/min): $1.2(1) ; 2.0$ (2) and $2.9(3)$

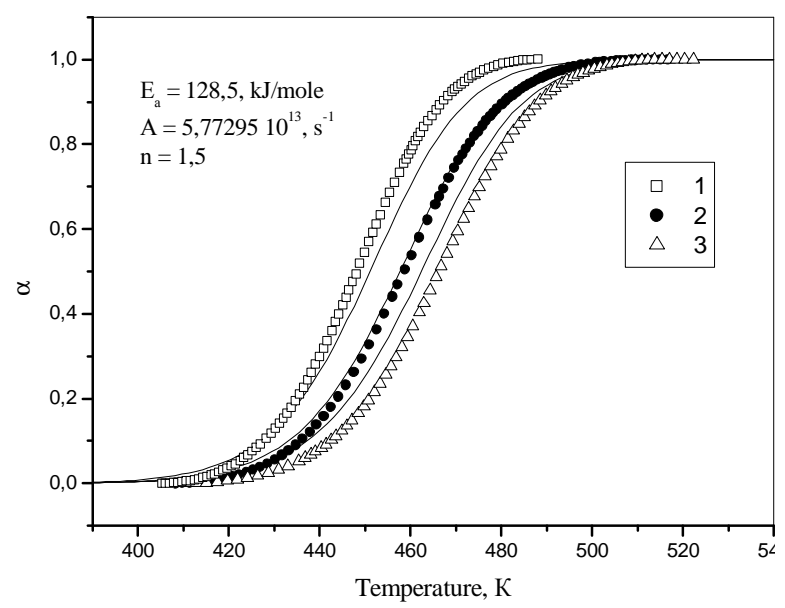

Fig. 4. Relationship of the degree of the completion of FOPCC and DETA interaction reaction with integrated values of $E_{a}$ and $A$ for different heating rates (K/min): $1.2(1) ; 2.0$ (2) and $2.9(3)$

Table 2

Characteristics of the thermal effects of the FOPCC and HMDA interaction reaction

\begin{tabular}{|c|c|c|c|}
\hline$\beta, \mathrm{K} / \min$ & $T_{\max }, \mathrm{K}$ & $\alpha_{\max }$ & $(\partial \alpha / \partial T)_{\max } \cdot 10^{-2}, \min ^{-1}$ \\
\hline 1.2 & 448.9 & 0.52 & 2.63 \\
\hline 2.0 & 458.8 & 0.5 & 2.36 \\
\hline 2.9 & 466.8 & 0.51 & 2.32 \\
\hline
\end{tabular}

Table 3

Kinetic parameters of the FOPCC and HMDA reaction of urethane formation

\begin{tabular}{|c|c|c|c|c|}
\hline$\beta, \mathrm{K} / \mathrm{min}$ & $E_{a}, \mathrm{~kJ} / \mathrm{mol}$ & $A, \mathrm{~s}^{-1}$ & Correlation coefficient $r$ & $n$ \\
\hline 1.2 & 144.9 & $7.2448 \mathrm{E} 15$ & 0.99885 & 1.5 \\
\hline 2.0 & 128.5 & $5.77295 \mathrm{E} 13$ & 0.99933 & 1.5 \\
\hline 2.9 & 137.0 & $4.38365 \mathrm{E} 14$ & 0.99839 & 1.5 \\
\hline
\end{tabular}



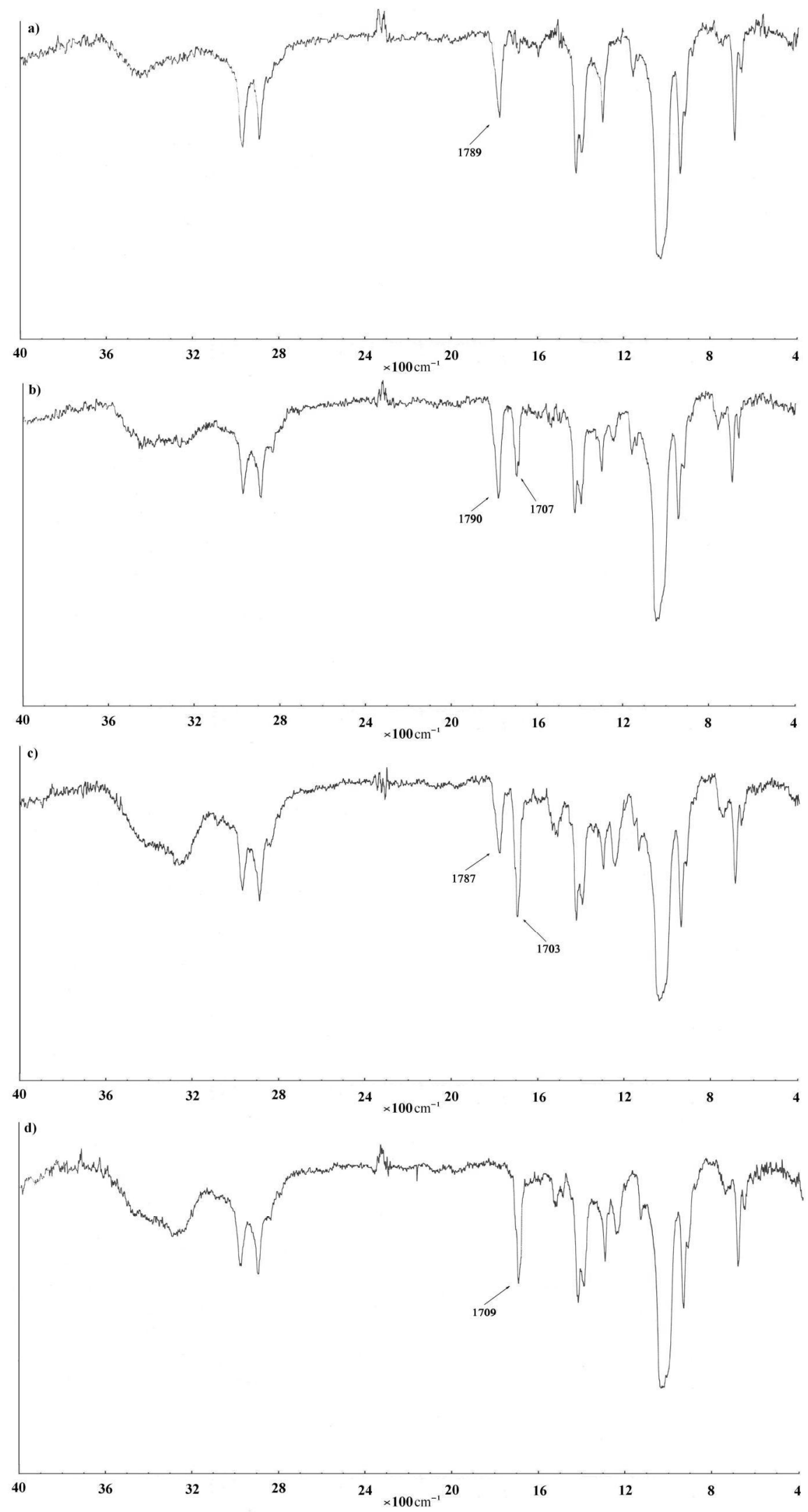

Fig. 5. IR spectra: initial mixture of FOPCC and HMDA with 2:1 ratio (a); the reaction mixture after 30 min of the reaction (b); the reaction mixture after $1 \mathrm{~h}$ of the reaction (c) and the reaction mixture after $2.5 \mathrm{~h}$ of the synthesis (d) 
It is obvious from Fig. 5 that the absorption band during the synthesis of monomer I at $1789 \mathrm{~cm}^{-1}$ (Fig. 5a) that corresponds to the valence vibrations of carbonyl group in the cyclocarbonate ring gradually disappears (Figs. 5b and 5c) and appears at $1709 \mathrm{~cm}^{-1}$ (Fig. 5d). This is related to the fact that the urethane formation reaction takes place and the vibrations of carbonyl group move to the range of lower frequencies. According to IR spectroscopy data the valence vibrations of carbonyl group $\left(1789 \mathrm{~cm}^{-1}\right)$, that are indicative of the presence of cyclocarbonate, totally disappear after $2.5 \mathrm{~h}$.

The experimental DSC thermograms of the reactions of the formation of the addition compound D-A at different heating rates are shown in Fig. 6.

Fig. 6 shows two thermal effects that are partially superimposed. The maximum of the first thermal effect for three heating rates is on average $360 \mathrm{~K}$, the maximum of the second thermal effect is on average $400 \mathrm{~K}$. The availability of two thermal effects is indicative of the progress of two different reactions. Addition compounds D-A are available in two isomeric forms: endo and exo. Depending on synthesis conditions an overwhelming majority of both endoisomer (at low temperatures of 293$338 \mathrm{~K}$ ), and exoisomer (at elevated temperatures of $\geq 363 \mathrm{~K})$ can be formed. Theoretically the synthetic reaction of exoisomer or isomerization of addition compounds D-A (endoisomer-to-exoisomer transformation) may correspond to the second thermal effect, because these take place at elevated temperatures. The detailed study of the nature of specified thermal effects will be the subject of future reports.

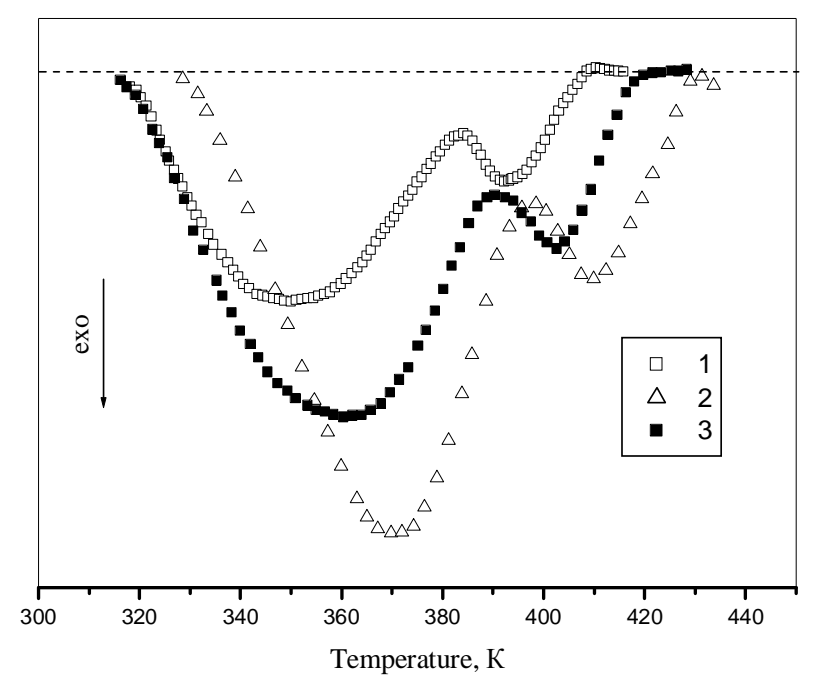

Fig. 6. Thermal effects of the formation of the addition compound as a result of the HMBM and FOPCC reaction for different heating rates (K/min): 1.2 (1); 2.1 (2) and 3.0 (3)
To perform the kinetic analysis using differential or isoconversion methods we need to know the total amount of the reaction heat. Since thermal effects are partially superimposed it is impossible to determine separately the total amount of heat for each thermal effect. Therefore, in this case we can use the Kissinger method that requires just the knowledge of the temperature of maxima for computations. Fig. 7 gives the data of these computations.

Kinetic computations show that the urethane formation reaction is more energy-intensive in comparison with the D-A reaction and therefore we conducted first the synthesis of the furan-bearing diglycol urethanes and oligoglycol urethanes and then proceeded to the final step of the PHU synthesis using the D-A reaction with HMBM; PHU physical and mechanical properties are given in Table 4. For the convenience of notations the Table gives only the names of furan-bearing hydroxyurethanes.

The previous research showed that FGE and its derivatives polymerize in the presence of COC following ion radical and oxyradical mechanisms [10]. The polymerization occurs due to the double bonds of the furan ring. Synthesized monomers I, II, and III also have furan rings in their structure and therefore their polymerization in the presence of $\mathrm{COC}$ is of great interest. We used COC $-\mathrm{Et}_{3} \mathrm{PhCH}_{2} \mathrm{~N} \cdot \mathrm{FeCl}_{4}$ in the amount of $1 \%$ for the polymerization (the previous research shows that this is the most active catalyst [10], the reaction proceeds at $453 \mathrm{~K}$. The physical and mechanical properties of the synthesized polymers are given in Table 5. All the coatings have 1 point adhesion.

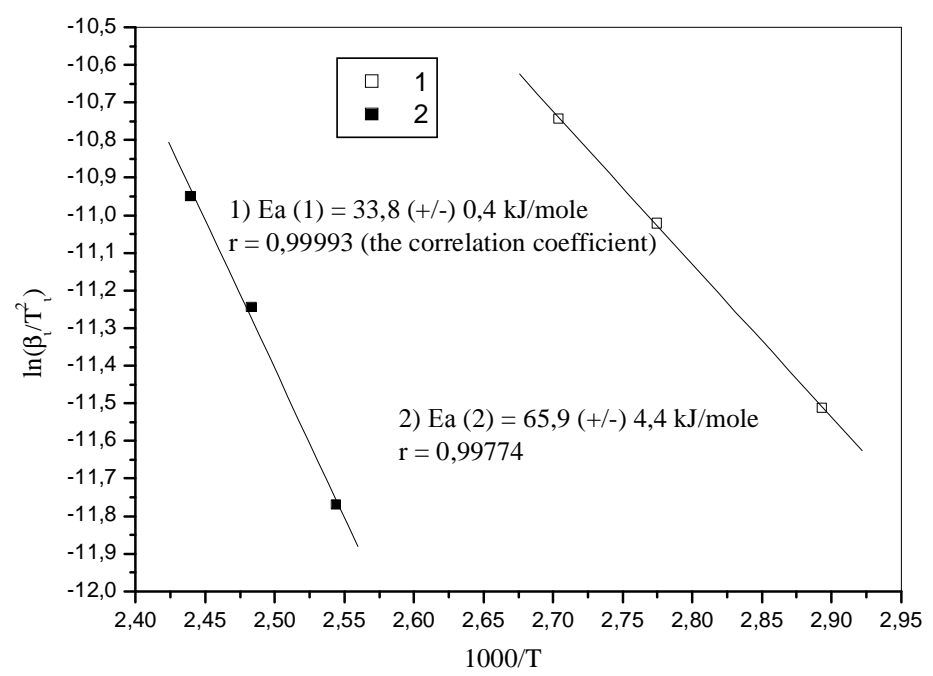

Fig. 7. The analysis of experimental data using the Kissinger method. The symbols show the experimental data; straight lines correspond to the results of mathematical processing in the coordinates of the Eq. (6): kinetic parameters of the first thermal effect (1) and kinetic parameters of the second thermal effect (2) 
Physical and mechanical properties of PHU

\begin{tabular}{|c|c|c|c|c|c|}
\hline \multirow{2}{*}{$\begin{array}{c}\text { Polymer } \\
\text { composition }\end{array}$} & \multirow{2}{*}{ Hardness, s } & \multirow{2}{*}{ Impact, $\mathrm{N} \cdot \mathrm{cm}$} & \multirow{2}{*}{ Bend, mm } & \multicolumn{2}{|c|}{ Gel fraction, $\%$} \\
\hline & & & & acetone & DMAA \\
\hline M I & 163 & 98.1 & 5 & - & - \\
\hline M II & 113 & 490.5 & 1 & - & - \\
\hline M III & 170 & 294.3 & 1 & 95 & 9 \\
\hline $\begin{array}{l}\text { M III/M I } \\
(0.75 / 0.25)\end{array}$ & 150 & 343.3 & 1 & 87 & 19 \\
\hline $\begin{array}{l}\text { M III/M II } \\
(0.25 / 0.75)\end{array}$ & 138 & 392.4 & 1 & 80 & 17 \\
\hline $\begin{array}{l}\text { M III/M II } \\
(0.75 / 0.25)\end{array}$ & 145 & 441.5 & 1 & 88 & 15 \\
\hline $\begin{array}{l}\text { M III/M II } \\
(0.25 / 0.75)\end{array}$ & 130 & 490.5 & 1 & 90 & 10 \\
\hline
\end{tabular}

Table 5

Physical and mechanical properties of PHU formed in the presence of $\mathrm{Et}_{3} \mathrm{PhCH}_{2} \mathrm{~N} \cdot \mathrm{FeCl}_{4}$

\begin{tabular}{|c|c|c|c|c|}
\hline Hardness, $\mathrm{s}$ & Impact, N·cm & Bend, mm & $\begin{array}{c}\text { Drying time to the } \\
\text { degree 3, min }\end{array}$ & $\begin{array}{c}\text { Gel-fraction (DMAA), } \\
\%\end{array}$ \\
\hline \multicolumn{5}{|c|}{ Monomer I } \\
\hline \multicolumn{5}{|c|}{ Monomer II } \\
\hline 145 & 392.4 & 1 & 75 & 90 \\
\hline \multicolumn{7}{|c|}{ Monomer III } \\
\hline 125 & 490.5 & 1 & 60 & 92 \\
\hline
\end{tabular}

It is obvious from Fig. 4 that physical and mechanical properties of PHU can be changed depending on the composition and structure of furan-bearing hydroxyl urethanes. The gel-fraction in acetone for all cross-linked polymers is mainly high, and gel-fraction in DMAA is mainly low. This is indicative of the fact that the retrodiene reaction progresses in high-boiling solvent (DMAA), therefore the gel-fraction is low. In the low boiling solvent (acetone) the gel-fraction is high, therefore the retrodiene reaction fails to progress at acetone-boiling temperature. In the presence of $\mathrm{COC}$ thermally irreversible PHUs of a cross-linked structure are formed.

\section{Conclusions}

1. New "nonisocyanate" PHUs of linear and crosslinked structures were synthesized based on renewable raw material sources and their physical and mechanical properties have been studied.
2. The kinetics of the urethane formation reaction and the Diels-Alder reaction of the formation of the addition compound was studied using the DSC method

3. The method of IR-spectroscopy was used for studying the urethane formation reaction between the FOPCC and the aliphatic diamines of a different structure.

4. Depending on the synthesis conditions both thermally reversible PHUs (due to D-A reaction) and thermally irreversible PHUs (due to the ion radical polymerization in the presence of $\mathrm{COC}$ ) have been obtained.

\section{References}

[1] Demirbas A.: Energy Sources A, 2010, 32, 1.

[2] Ali S., Selen G., Burzin U. et al.: Energy Conversion and Management, 2010, 51, 612.

[3] Chareonlimkun A., Champreda V., Shotipruk A. et al.: Biores. Techn., 2010, 101, 4179.

[4] Selhan K., Thallada B., Akinori M. et. al.: Fuel, 2005, 84, 875.

[5] Boisena A., Christensena T., Fub W. et al.: Chem. Eng. Res. \& Design, 2009, 87, 1318. 
[6] Shapovalov L., Figovskiy O. and Kudryavsev B.: Voprosy Khimii i Khim. Techn., 2004, 1, 231.

[7] Yoxi H., Lijun O., Yusheng Q. et al.: Macromolecules, 2009, 42, 9251.

[8] Dean C.: Progr. Org. Coat., 2003, 47, 77.

[9] Takeshi E.: Prepr. Pap.-Am. Chem. Soc., Div. Fuel Chem, 2004, 49, 112 .

[10] Litvinov D.: PhD thesis, National Technical University "KPI", Kyiv 2011.

[11] Gandini A., Coelho D. and Armando J.: Eur. Polym. J., 2008, 4, 4029.

[12] Aliev Z., Karateev A. and Atovmian L.: Koordin. Khimia, 1988, 14, 530 .

[13] Aliev Z., Karateev A. and Atovmian L.: ibid, 111.

[14] Bernstein V. and Egorov V.: Differentsialnaya Scaniruushaya Kalorimetria v Physicheskoi Khimii Polymerov. Khimiya, Leningrad 1990.

[15] Kramarenko V.: Ukr. Khim. Zh., 2007, 73, 58.

\section{"НЕІЗОЦІАНАТНІ" ПОЛІГІДРОКСИУРЕТАНИ НА ОСНОВІ СИРОВИНИ РОСЛИННОГО ПОХОДЖЕННЯ}

\begin{abstract}
Анотація. Синтезовано нові “неізоціанатні” полігідроксиуретани (ПГУ) на основі фурфурилоксипропілциклокарбонату (ФОПЦК) - продукту перероблення відновлюваної сировини. Методом інфрачервоної спектроскопї̈ досліджено реакиію уретаноутворення. Методом диферениійноскануючої калориметрії вивчена кінетика реакцій утворення ПГУ: реакція уретаноутворення $і$ реакиія Дільса-Альдера. Показана можливість полімеризації похідних ФОПЦК у присутності комплексного онієвого каталізатора. Одержано як термооборотні, так і термонеоборотні сітчасті ПГУ.
\end{abstract}

Ключові слова: неізочіанатні полігідроксиуретани, відновлювальна сировина, фурфурилоксипропілциклокарбонат, реакція уретаноутворення, реакція Дільса-Альдера. 